\title{
Merkel Cell Carcinoma pN1b TNM Finding v7
}

National Cancer Institute

\section{Source}

National Cancer Institute. Merkel Cell Carcinoma pN1b TNM Finding v7. NCI Thesaurus. Code C88530.

Merkel cell carcinoma with macrometastasis in regional lymph node(s). Macrometastases are defined as clinically detectable nodal metastases confirmed by therapeutic lymphadenectomy or needle biopsy. (from AJCC 7th Ed.) 